\title{
The Immuno-Endocrine System: Hormones, Receptors and Endocrine Function of Immune Cells. The Packed-Transport Theory
}

\author{
G. Csaba* \\ Department of Genetics, Cell and Immunobiology, Semmelweis University, Budapest, Hungary
}

\begin{abstract}
Immune cells (lymphocytes, monocytes and macrophages, granulocytes and mast cells) produce numerous hormones, store and secrete them. In addition these cells have receptors for hormones and signal transduction pathways. These functions are under the control of the central nervous system (neuro-immune regulation), and there is a dynamic multi-directional interaction within the neuroimmune circuitry. Considering the high amount of immune cells, their hormone production can rival to that of the "classical" endocrine glands. However, in contrast to the endocrine glands, which are in general mono-producers, 1.) the immune cells are poly-producers, the same cell can produce different hormones at the same time and also poly-receivers, having receptors for different hormones, 2.) immune cells are mobile and can transport the hormones in a packaged form, even though they are able to synthesize and secrete the hormones locally. 3.) immune cells have the capacity to recognize the site where their hormones are needed. It is proposed that under the control of the nervous system immune cells produce hormones for general regulation, for intrasystem regulation and for remote, local regulation. Hormone production is gender dependent. Receptors are affected by hormonal imprinting during the critical developmental periods of target cells and the imprinting influences also the hormone synthesis of immune cells for life. Some hormones can be demonstrated in the nucleus of mast cells, however their function is not known. The knock-out of one hormone's gene disturbs hormone balance in immune cells. The importance of the packed-transport hypothesis is discussed.
\end{abstract}

Keywords: Immune cells, hormone synthesis, hormone content, hormone transport, local effects

\section{INTRODUCTION}

The classical endocrine system is composed of a few endocrine organs, which produce hormones (signal molecules) which are responsible for the hormonal regulation of the organism. The hormones bind to the specific receptors of the cells to be regulated. Later numerous new sources of hormones and hormone producing cell groups were recognized, which broadens the spectrum of the endocrine system. This means that the concept of the "endocrine system" has to be modified according to our technical development.

${ }^{*}$ Correspondence to: Gyorgy Csaba, Department of Genetics, Cell and Immunobiology, Semmelweis University, Budapest, Hungary. E-mail: csagyor@dgci.sote.hu.
More than 150 years ago Claude Bernard proposed that not only the endocrine glands, known in his time are able to produce homeostasis regulating signal molecules, but also other-non endocrine- cells [8, 115]. This was an ingenious guess however, it is not surprising in the light of recent results: already at the lowest phylogenetic levels, -the unicellular Tetrahymenasynthesizes a treasury of signal molecules [43, 44], functionally and structurally similar or identical to mammalian hormones [39, 121-123]. These signal molecules influence the other members of the population, as hormone receptors-similar to mammalian ones- are also present in the membrane of these cells [38]. Microbes (bacteria, yeast and fungi) are also contain some hormones [120] however, their receptors and functions have not been examined. 
In the eighties of the last century J.E. Blalock and co-workers demonstrated polypeptide hormones in immune cells $[16,33,172]$ and since this time many -not only polypeptide- hormones were observed in different cells of the immune system. Hormone receptors and influence on immune function were also found. This was the dawn of the neuro-immune concept, which is absolutely accepted today $[14,15,34$, $135,160,191]$. Not denying the priority of the neuroimmune regulation, here the endocrinology of the immune system will be discussed.

\section{THE IMMUNO-ENDOCRINE REGULATION}

\section{Proopiomelanocortin (POMC) regulation}

The POMC gene is present in the pituitary gland, giving information for production of different peptides. These are the adrenocorticotropin (ACTH), melanotropin, lipotropin and the endorphins. However, the presence and secretion of biologically active ACTH and beta endorphin were demonstrated in rat mononuclear blood cells [21, 39, 175], later the quantitative determination of ACTH was also done and the presence of POMC gene in lymphocytes was demonstrated $[11,96,148]$. By using immunocytochemical method, ACTH (Fig. 1) and endorphin were demonstrated also in human immune cells, granulocytes included [58]. Both B and T lymphocytes produce ACTH and endorphin $[92,155]$. Although some authors deny the existence of lymphocyte-derived POMC [195], the evidence in favour of positive results is overwhelming.

Lymphocytes not only produce and secrete ACTH, but have receptors for it [20]. In addition, these cells

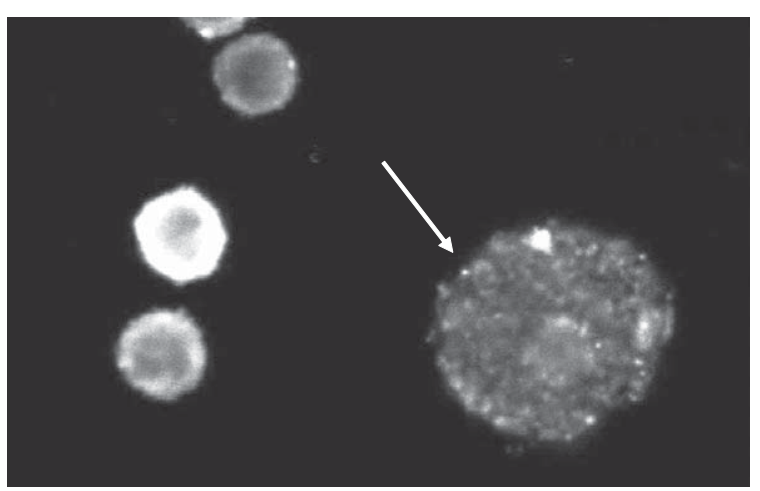

Fig. 1. Three lymphocytes and a mast cell. Anti-ACTH antibody. In the mast cell the nucleus and the granules are intensively fluorescing, while in the lymphocytes the cytoplasm contain the fluorescing material and the nucleus is paler. (Csaba and Kovács, Horm Metab Res 41, 2009, 621-625). (as well as macrophages and mast cells) have corticotropin releasing factor (CRF) receptors [29, 98], by which ACTH and endorphin production can be stimulated $[35,107,136]$. The receptor-hormone connection can be disturbed by exogenous factors, e.g. by chronic alcohol abuse [165, 193].

The presence of POMC receptors on the surface of immune cells makes it possible to instruct such cells by the neuroendocrtine system and by various immune cells. This instruction can influence (by CRF receptor) the ACTH and endorphin production, by ACTH receptor the immune response and by endorphin the pain, caused by inflammation. ACTH induces the production of cyclic AMP [104], activating some immune processes; increases B lymphocyte proliferation [23]; stimulates transient calcium uptake [40]; modulates IL2- production from (concanavalin A) activated lymphocytes [192]; initiates antibody production [135] and decreases TGF beta production [74]. POMC derived hormones are potent inhibitors of the antibody response in vitro [92]. It is generally accepted that ACTH and endorphin are potent immunoregulators directly affecting immune cells or influencing the production of other immunologically competent hormones [9, 18, 125, 126]. Lymphocyte derived ACTH, cooperating with other hormones may have special role in the maintenance of pregnancy [78].

The role of endorphin in calming pain in the case of inflammation, where a mass of immune cells are present seems to be unequivocal. However, it is interesting that in men more endorphin is present in (and may be secreted by) granulocytes, than lymphocytes. Granulocytes show an outstanding presence in the inflamed area [17, 36, 155].

\section{Regulation by thyroid hormones}

The thyroid hormone, triiodothyronine (T3) is present in immune cells. Not only lymphocytes of the blood, but also the peritoneal fluid and thymus contain this hormone. In addition, T3 was demonstrated in other members of the immune system, such as monocytes, macrophages, granulocytes and mast cells [55]. The cells do not take up T3 (produced by the thyroid gland) from the blood circulation but the hormone -in a bioactive form- is generated by immunocytes [174]. These cells have also enzymes for converting thyroxine (T4) to T3 [171].

The thyroid hormone receptor belongs to the steroid receptor superfamily, which is localized in the nucleus and cytoplasm of the cells and can bind both T3 and T4. There is a similar situation in the case of the immune 
cells, where these receptors were demonstrated in animal (rat) and human immune cells [117, 134, 169]. This means that there is a possibility of regulation of the function of these cells by the thyroid hormones produced by the thyroid gland, by the neighbouring immune cells (paracrine regulation) or by autologous stimulation (autocrine regulation).

Lymphocytes produce immunoreactive thyrotropin (TSH) when they are treated with a T cell mitogen [174], or stimulated by thyrotropin releasing hormone (TRH) [94]. However, TSH regulates T3 concentration in the immune cells both in vivo and in vitro [68] and this means, that TSH receptor is also present in (on) the immune cells. The sensitivity of receptor is very high, not more than $0.1 \mathrm{mU} \mathrm{TSH} / \mathrm{ml}$ cell suspension is enough for provoking 50\% increase of T3 production. At the same time TSH can enhance the antibody response [19]. The whole circuit, which is characteristic in the case of the thyroid gland can be found: TRH enhances TSH production of the immune cells [114], and this latter increases T3 production [68].

Although the specific enzymes were not studied, it seems likely that the immune cells (first of all lymphocytes) have the same machinery which is present in the thyroid gland. This is supported by the fact that thiamazole, an antithyroid drug can influence T3 production by immune cells [56]. Thiamazole (methimazole) inhibits the enzyme thyroperoxidase which have a key role in T3 synthesis. [74]. This means that this enzyme is also present in the immune cells.

What is the function of the TSH-T3 production and reception in the immune system? There are many experiments demonstrating immune stimulatory and inhibitory effects. Some results point to the effect of TSH-T3 on the number and maturation of immune cells. Experiments demonstrated the increasing concentration of growth hormone in the serum -caused by TSH- which influenced the growth of lymphoid organs and the production of lymphocytes [90], while other experiments (in an other species) did not justify this [183]. TSH needed for the in vitro antibody production [113], and functions as a lymphokine [113]. In in vitro conditions it regulates the immune response [114]. Thyroid hormone deficiency reduced lymphocyte production [4] and receptor binding capacity [100], however T4 inhibited $\mathrm{T}$ cell cytokine production [196]. T3 regulates dendritic cell maturation and function [133] and helps to express interleukin receptor on peripheral blood mononuclear cells [146]. The results are partial and sometimes contradictory, demonstrating that the thyroid hormones can influence immune events, however the real target of the hormonal effect is unclear. In addition it is not known whether the circulating (thyroidal) hormones are responsible for the experimental results in natural conditions, or the hormones produced by the immune cells themselves.

\section{Other hormones and their receptors}

\section{Melatonin}

This hormone was isolated from the pineal body more than half century ago, because of this, for a long time the pineal was believed as a sovereign source of it. However, in the last time the synthesis and presence in and secretion by the immune cells were demonstrated [130]. The basic molecule, tryptophan is consumed by the cells [84] and the four enzymes (tryptophan hydroxylase, aromatic amino acid decarboxylase, serotonin $\mathrm{N}$-acetyl transferase and hydroxyindole-O-methyltransferase) which are needed for the production of melatonin are present in lymphocytes [30]. In the presence of excess tryptophan the production of serotonin and melatonin increases [131].

Not only the hormone synthesizing machinery, but melatonin receptors are also present in lymphocytes. These receptors can react to exogeneous melatonin (e.g. which is secreted by the pineal body), and by this they respond in a circadian fashion $[22,110,163]$ and a regular transduction pathway was demonstrated, resulting the inhibition of adenylate cyclase and stimulation of phospholipase $C$ [87]. These receptors can be specifically inhibited by luzindole or thiazolidine diones.

It is supposed that lymphocyte-derived melatonin can act as an intracrine, autocrine or paracrine regulator [30]. Its effect is manifested in the increase of antigen presentation and $\mathrm{T}$ cell proliferation [162], induction of $\mathrm{T}$ helper cell activity and IL-2 production and release [32] by $\mathrm{T}$ helper cells and IL-12 release by dendritic cells [124]. It also stimulates the production of NK cells, CD4 + and of progenitor cells for granulocytes-macrophages, while inhibits CD8 + cells $[28,162,176]$.

\section{Growth hormone (GH)}

$G H$ is produced by mononuclear leukocytes and this was demonstrated by RNA analysis and by immunocytochemical methods (Fig. 2) [46, 187, 189]. This hormone is identical with pituitary GH in bioactivity, antigenicity and molecular weight [187]. Studying lymphocyte subpopulations, a heterogeneity in their ability to produce $\mathrm{GH}$, was found however, B cells, macrophages, $\mathrm{T}$ helper cells, cytotoxic $\mathrm{T}$ cells as well 


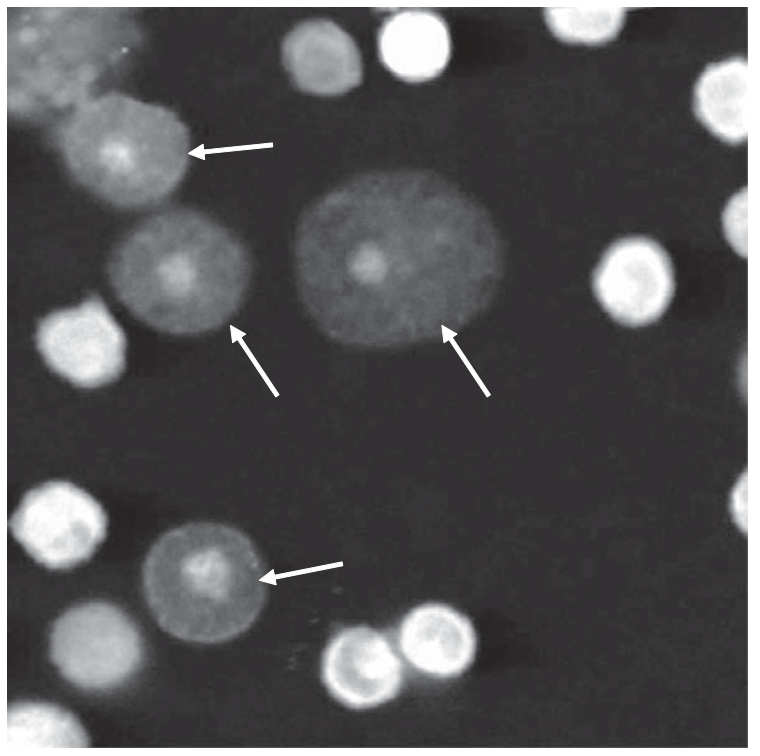

Fig. 2. Four mast cells and lymphocytes after anti-GH treatment. The strong fluorescence in the mast cell nucleus is clearly visible. Lymphocytes are also lightning. (Csaba and Kovács, Horm Metab Res 41, 2009, 621-625.

as NK cells have RNA with GH-information. In addition, growth hormone releasing hormone (GHRH) and receptors for this hormone also can be found in lymphocytes [89, 188].

GH stimulates $\mathrm{T}$ and $\mathrm{B}$ cell proliferation and immunoglobulin synthesis, modulates cytokine response, enhances the maturation of myeloid progenitor cells [112, 129, 137, 197], and thymic functions $[86,106]$. It seems to have some interaction with lectin $[75,166]$. There is also an autocrine function, by which it maintains immunocompetence [12]. The effects do not require a transmitter, as they are direct effects [112, $129,166]$. GH produced by immune cells did not influence weight gain in dwarf mice [190] however this does not exclude an effect locally.

\section{Insulin (INS)}

INS was found in macrophages and granulocytes as well as in peritoneal fluid and thymic lymphocytes [55]. If resting lymphocytes were activated by a mitogen (concanavalin A) an mRNA with information for insulin receptor appeared and also cryptic insulin receptors in the plasma membrane have been exposed [88]. Insulin can influence the content of other hormones (histamine and T3) in lymphocytes both in vitro and in vivo [57].

\section{Gonadotropins}

Blalock and his coworkers investigated thymocytes and found that a luteinizing hormone releasing hormone (LHRH)-like molecule -with similar bioactivity and antigenicity to hypothalamic LHRH)-was produced [95, 128]. This was followed by experiments demonstrating human chorionic gonadotropin (HCG) secretion by mononuclear white blood cells (first of all monocytes and NK cells) during pregnancy [1]. The HCG could have a first and decisive role during early pregnancy, ensuring tolerance to the half-foreign embryo [184].

\section{Prolactin (LTH)}

The lactogenic hormone of the pituitary gland is also produced by immune cells [13], and the cells also have receptors for the hormone, which seems to be common with the receptors for GH. Different subtypes of immune cells, mainly $\mathrm{B}$ and $\mathrm{T}$ lymphocytes synthesize prolactin [24, 140], and this is influenced by the pituitary gland, as the prolactin production of lymphoid tissue was strongly reduced after hypophysectomy $[12,145]$.

Prolactin is a multifunctional immune regulator [108], which participates dendritic cell maturation [103], influences B cell, NK cell and macrophage function [12, 159], and behaves as a cytokine [138]. In the last time the elevation of prolactin level in autoimmune diseases was demonstrated and its role in the autoimmune process was surmised [73, 103, 138].

\section{Leptin (LEP)}

LEP synthesis in immune cells is not known. However, leptin receptors are present in lymphocytes. By using these receptors leptin has an important role as a mediator of inflammatory reaction [83, 109, 132], influences the proliferation of CD4 + cells [7, 109] and induces GH secretion of blood mononuclear cells [77].

\section{Histamine (HIS)}

It is generally accepted that HIS is present in mast cell granules [41, 64, 80, 168] and this biogenic amine is secreted by degranulation [80]. However, lymphocytes, macrophages and granulocytes also produce histamine, and contain histidin decarboxylase (HDC) enzyme [52, 147]. Histamine can be demonstrated already in lymphatic cells of newborn rats [156]. Mast cell derived histamine has important role in inflammatory and allergic reactions and many immune processes [81] directly or influencing the cytokine balance [102, 149]. 


\section{Serotonin (5HT)}

An other biogenic amine, 5HT was also found in mast cell granules [41, 64, 168]. Later it was cleared that $5 \mathrm{HT}$ is also present in mononuclear blood cells as well, as in macrophages [5, 51, 52, 147, 156]. In blood lymphocytes a serotonin transporter was demonstrated [6] and also serotonin receptor, the inhibition of which by $5 \mathrm{HT}$ antagonists hampered $\mathrm{T}$ lymphocyte function and cell mediated immunity [5]. 5HT participates in a lot of immune reactions, influencing lympokine secretion [151], interferon gamma production [97], splenic T lymphocytes [198] and dendritic cells [144].

\section{Hormonal imprinting of immune cells}

Hormonal imprinting takes place perinatally, in a critical period, when the first encounter between a hormone and its developing target receptor, causes a change in the cell's response for life [42-44]. During this critical period, the presence of foreign molecules which also can bind to the receptor cause faulty imprinting also with life-long consequences. In addition, there are other critical periods, e.g. weaning when the continuously dividing cells, as the blast cells of immune cells are also sensitive to imprinting. This imprinting could also change the other hormones' content in the imprinted cells. If female rats are treated with beta endorphin in the 19th day of pregnancy, lymphocyte, monocyte and granulocyte serotonin content is reduced when adult [58], while histamine content of monocytes and granulocytes increased. Neonatal imprinting with vitamins A or D [61], or benzpyrene [65] can dramatically influence the hormone content of adult rat white blood cells. When the animals were treated at weaning or in adult age, with endorphin, serotonin or an antihistamine; serotonin, histamine or endorphin content of immune cells were changed for a long time [52-54]. This means that the cells of the immune system can be always hormonally imprinted and these effects have lifelong influence on the hormonal activity of immune cells.

The effect of perinatal hormonal imprinting can be transgenerationally transmitted. Neonatal imprinting by vitamin A almost doubled the offsprings' ACTH and $\mathrm{T} 3$ content in the immune cells [60], and beta endorphin exposure of the dams in late pregnancy changed histamine and serotonin content of immune cells up to the third generation [50, 157].

\section{Hormones in the nucleus of immune cells}

The entrance of hormones binding to the steroid receptor superfamily into the nucleus of immune cells is well known [194]. Recently it was clarified that polypeptide hormones and biogenic amines are also localized in the nucleus of some immune cells. Using isotope labelled hormones [70] or immunocytochemical method combined with confocal microscopy [59] the presence of serotonin and histamine in the nucleus of lymphocytes as well, as in the mast cells were demonstrated. In this latter cells ACTH and GH were also shown [46] (Figs. 1-3). Not all of the polypeptide hormones were present: insulin and endorphin could not be demonstrated. The hormones (biogenic amines) can be observed also in a perinuclear localization [45]. As these observations are new, there are no data on the
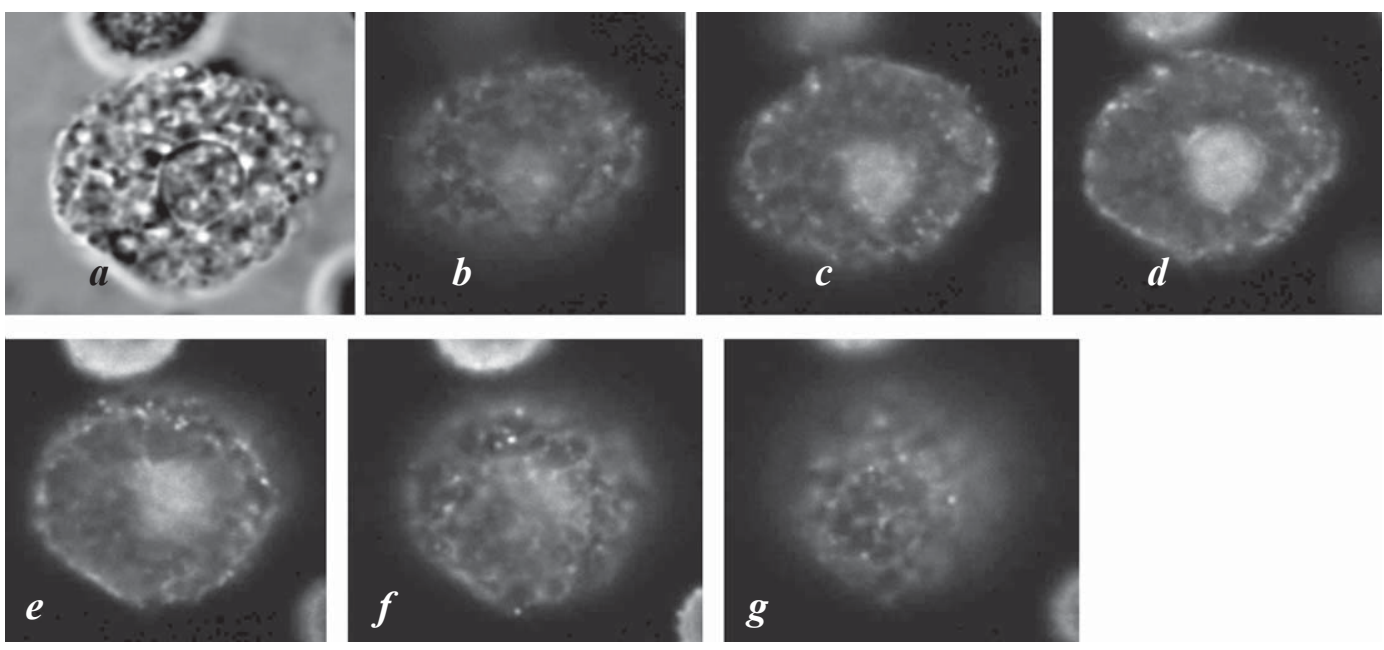

Fig. 3. Serial optical sections of a mast cell, treated with anti-ACTH antibody. a) transmission microscopic picture, b-g) serial optical sections with $2 \mathrm{~mm}$ distance. (Csaba and Kovács, Horm Metab Res 41, 2009, 621-625. 

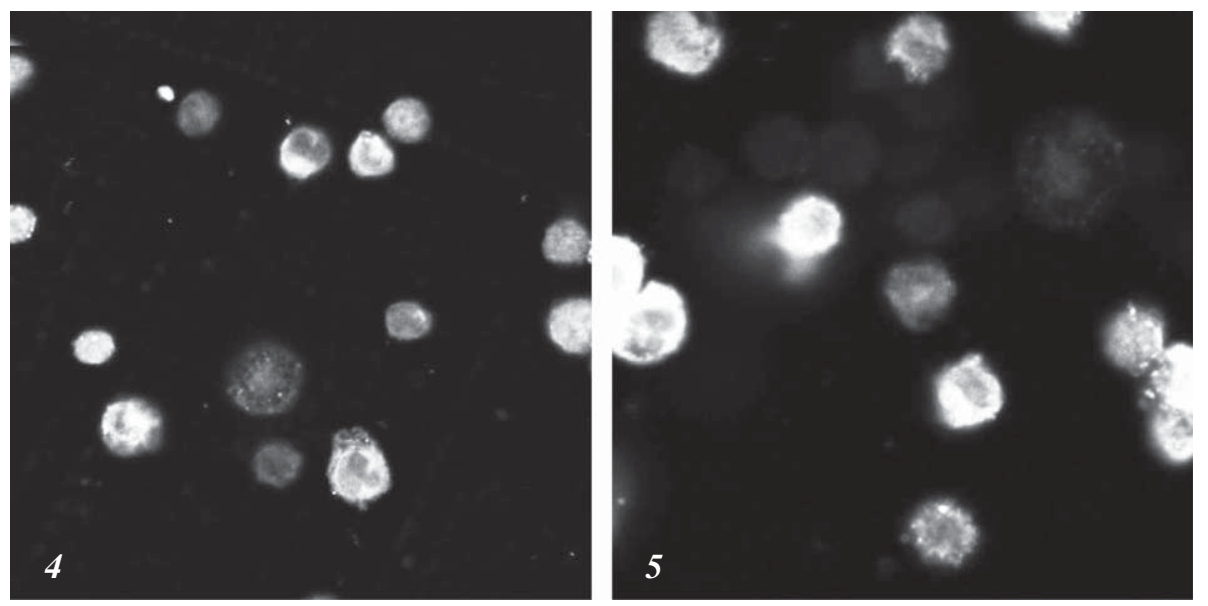

Fig. 4,5. Control (4) and serotonin-treated (5) peritoneal cells, T3 antibody. In vitro experiment. T3 is present in the nucleus of mast cells and lymphocytes' cytoplasm and serotonin increased its content. Magnification: 1300x; 1500x resp.(Csaba et al., Cell Biol Int 31, 2007, 224-228).

physiological role of nuclear entrance of amino acid and polypeptide hormones. It could be supposed that they have a role similar to that of the steroid hormones or thyroxine (Figs. 4, 5) however, nuclear receptors for these hormones are not known. Considering this, further research is needed for clearing their role in the nucleus.

\section{Stress and immune cells}

According to Hans Selye there is an interaction between the neuroendocrine and immune system during stress [11]. As a consequence of this interaction, psychological stress can influence immune function [150], however other stress conditions does the same. Transport of animals affects ACTH secretion from bovine lymphocytes [76]. T3 and serotonin concentrations of immune cells decrease in the last hours of prolonged stress caused by long food and water deprivation [154]. This food and water deprivation just before and after delivery in rat dams caused elevation of ACTH in immune cells of the offspring, in adult age [71] (Table 1). Such a deprivation in weanling rats caused also disturbances in hormone (T3 and histamine) production two months later [63]. This means that stress is able to influence immunity not only during and just after the event, but it causes (hormonal) imprinting, probably by touching the endocrine balance inside the continuously developing immune cells.

\section{Alcohol and immune cells}

Alcohol abuse has a deteriorating effect on the immune system [178], while moderate and permanent alcohol consumption helps it [164]. These effects are manifested through the alterations of immune cells. Antigen presenting cell function and $\mathrm{T}$ cell functions are directly influenced by alcohol abuse [177] as well as the production of cytokines [72]. However, the imprinting effect of alcohol also must not be underestimated.

Table 1

Influence of stress before birth $(\mathrm{BB})$ and after birth $(\mathrm{AB})$ on the hormone content of the peritoneal immune cells in adult male rats (Geo-mean \pm SD) (Csaba et al., Horm Metab Res 41, 2009, 617)

\begin{tabular}{lclll}
\hline Group & \multicolumn{1}{c}{ ACTH } & \multicolumn{1}{c}{ Histamine } & \multicolumn{1}{c}{ Serotonin } & T3 \\
\hline lymph. C & $75.0 \pm 19.2$ & $126.7 \pm 6.2$ & $329.6 \pm 42.4$ & $137.8 \pm 8.8$ \\
lymph.BB & $\mathbf{1 3 7 . 6} \pm \mathbf{1 4 . 4} *$ & $134.0 \pm 7.8$ & $333.6 \pm 92.5$ & $143.6 \pm 10.5$ \\
lymph.AB & $95.5 \pm 6.1$ & $\mathbf{1 5 8 . 0} \pm \mathbf{2 4 . 0} *$ & $278.0 \pm 20.8$ & $157.6 \pm 19.4$ \\
mo-gran.C & $120.3 \pm 7.5$ & $268.2 \pm 21.7$ & $561.0 \pm 53.0$ & $289.2 \pm 27.9$ \\
mo-gran.BB & $\mathbf{2 6 9 . 6} \pm \mathbf{3 5 . 9} * *$ & $202.6 \pm 24.1$ & $650.6 \pm 119.9$ & $301.3 \pm 50.8$ \\
mo-gran.AB & $\mathbf{1 8 0 . 0} \pm \mathbf{1 0 . 0} * *$ & $291.6 \pm 27.0$ & $541.0 \pm 22.3$ & $\mathbf{3 3 9 . 0} \pm \mathbf{2 2 . 3} *$ \\
mast.C & $140.6 \pm 4.2$ & $232.8 \pm 9.4$ & $405.6 \pm 37.1$ & $288.4 \pm 18.0$ \\
mast.BB & $\mathbf{2 3 5 . 0} \pm \mathbf{2 0 . 2} * *$ & $\mathbf{2 1 7 . 0} \pm \mathbf{3 . 0} *$ & $395.6 \pm 54.6$ & $265.0 \pm 24.3$ \\
mast.AB & $\mathbf{1 9 6 . 7} \pm \mathbf{3 2 . 5} *$ & $246.0 \pm 33.4$ & $375.0 \pm 67.8$ & $317.0 \pm 37.1$ \\
\hline
\end{tabular}

$C=$ control; lymph = lymphocytes; mo-gran= monocyte-macrophage-granulocyte complex; mast = mast cells; $*=p<0.05 ; * *=p<0.01$ 
When alcohol was given for rats at the 3rd day of gestation, the offspring's immune cells in adult age produced significantly less insulin, than the controls [153]. There were expressed changes also in the offspring's serotonin production after treating the mother during late pregnancy or lactation [58].

\section{Gender and immune-endocrinology}

It is known that females' immune response is more active and autoimmune diseases has higher incidence in females [27, 37]. Immunomodulatory cytokines (interleukins and interferons) are produced by the immune cells gender dependently, influenced by sex hormones to which receptors are present on the immune cells $[2,27,161,186]$. The hormone production by immune cells of the two genders is also different. Adult female rats' lymphocytes, monocytes, granulocytes and mast cells contain more hormone (ACTH, endorphin, progesterone) than that of males [67], but T3 content of mast cells were higher in males. In young (four weeks old) females also higher values were observed, except ACTH (Tables 2, 3). This shows that sexual maturation does not influence hormone production.

Table 2

Comparison of the hormone contents in sexually unmatured male and female animals' white blood cells and mast cells. (Csaba and Pállinger, Acta Physiol Hung 96, 2009, 45-50)

\begin{tabular}{|c|c|c|c|c|c|}
\hline Gender & Source & Hormone & Cell & Geo-mean & Signif. $p<$ \\
\hline male & Blood & ACTH & lymphocyte & $21.01 \pm 6.44$ & \\
\hline female & & & & $12.87 \pm 3.27$ & 0.05 \\
\hline male & & endorphin & lymphocyte & $13.75 \pm 2.24$ & \\
\hline female & & & & $13.92 \pm 3.31$ & n.s. \\
\hline male & & progesterone & lymphocyte & $17.06 \pm 3.84$ & \\
\hline female & & & & $36.26 \pm 2.1$ & 0.001 \\
\hline male & & $\mathrm{T}_{3}$ & lymphocyte & $6.43 \pm 1.63$ & \\
\hline female & & & & $5.69 \pm 0.45$ & n.s. \\
\hline male & perit.fluid & ACTH & lymphocyte & $12.21 \pm 0.63$ & \\
\hline female & & & & $13.99 \pm 1.81$ & n.s. \\
\hline male & & ACTH & mo-gran & $20.37 \pm 2.39$ & \\
\hline female & & & & $28.65 \pm 3.44$ & 0.01 \\
\hline male & & ACTH & mast cell & $29.74 \pm 2.73$ & \\
\hline female & & & & $34.45 \pm 2.15$ & 0.02 \\
\hline male & & endorphin & lymphocyte & $9.19 \pm 0.44$ & \\
\hline female & & & & $11.09 \pm 0.74$ & 0.01 \\
\hline male & & endorphin & mo-gran & $17.9 \pm 1.74$ & \\
\hline female & & & & $24.63 \pm 1.31$ & 0.001 \\
\hline male & & endorphin & mast cell & $25.81 \pm 2.55$ & \\
\hline female & & & & $30.31 \pm 1.45$ & 0.01 \\
\hline male & & progesterone & lymphocyte & $33.07 \pm 1.89$ & \\
\hline female & & & & $26.66 \pm 3.57$ & 0.01 \\
\hline male & & progesterone & mo-gran & $7.04 \pm 0.55$ & \\
\hline female & & & & $7.58 \pm 0.64$ & n.s. \\
\hline male & & progesterone & mast cell & $9.62 \pm 0.48$ & \\
\hline female & & & & $11.19 \pm 0.24$ & 0.001 \\
\hline male & & $\mathrm{T}_{3}$ & lymphocyte & $5.44 \pm 0.46$ & \\
\hline female & & & & $7.73 \pm 0.56$ & 0.001 \\
\hline male & & $\mathrm{T}_{3}$ & mo-gran & $11.63 \pm 1.28$ & \\
\hline female & & & & $15.88 \pm 1.4$ & 0.01 \\
\hline male & & $\mathrm{T}_{3}$ & mast cell & $18.82 \pm 1.21$ & \\
\hline female & & & & $24.27 \pm 1.25$ & 0.001 \\
\hline male & Thymus & ACTH & lymphocyte & $5.79 \pm 1.7$ & \\
\hline female & & & & $5.81 \pm 1.73$ & n.s. \\
\hline male & & endorphin & lymphocyte & $5.98 \pm 1.07$ & \\
\hline female & & & & $7.11 \pm 3.05$ & n.s. \\
\hline male & & progesterone & lymphocyte & $1.7 \pm 0.03$ & \\
\hline female & & & & $1.81 \pm 0.09$ & 0.05 \\
\hline male & & $\mathrm{T}_{3}$ & lymphocyte & $3.93 \pm 0.82$ & \\
\hline female & & & & $7.0 \pm 1.43$ & 0.01 \\
\hline
\end{tabular}

n.s. = not significant; mo-gran = monocyte, macrophage, granulocyte group; perit $=$ peritoneal Signif $=$ intergender significance. 
Table 3

Comparison of the hormone contents in sexually matured male and female animals' white blood cells and mast cells. (Csaba and Pállinger, 96, 2009, 45-50)

\begin{tabular}{|c|c|c|c|c|c|}
\hline Gender & Source & Hormone & Cell & Geo-mean & Signif. $p<$ \\
\hline male & Blood & ACTH & lymphocyte & $9.85 \pm 1.18$ & \\
\hline female & & & & $14.22 \pm 4.22$ & n.s. \\
\hline male & & endorphin & lymphocyte & $14.06 \pm 2.9$ & \\
\hline female & & & & $12.28 \pm 2.38$ & n.s. \\
\hline male & & $\mathrm{T}_{3}$ & lymphocyte & $18.68 \pm 6.21$ & \\
\hline female & & & & $22.57 \pm 3.71$ & n.s. \\
\hline male & perit.fluid & ACTH & lymphocyte & $13.03 \pm 1.48$ & \\
\hline female & & & & $15.43 \pm 0.81$ & 0.05 \\
\hline male & & ACTH & mo-gran & $24.18 \pm 3.74$ & \\
\hline female & & & & $34.6 \pm 2.72$ & 0.01 \\
\hline male & & ACTH & mast cell & $24.29 \pm 3.46$ & \\
\hline female & & & & $26.31 \pm 0.99$ & n.s. \\
\hline male & & endorphin & lymphocyte & $10.22 \pm 0.51$ & \\
\hline female & & & & $11.35 \pm 0.93$ & 0.05 \\
\hline male & & endorphin & mo-gran & $19.22 \pm 0.67$ & \\
\hline female & & & & $26.69 \pm 2.48$ & 0.001 \\
\hline male & & endorphin & mast cell & $19.78 \pm 0.56$ & \\
\hline female & & & & $21.52 \pm 1.02$ & 0.02 \\
\hline male & & $\mathrm{T}_{3}$ & lymphocyte & $19.37 \pm 3.13$ & \\
\hline female & & & & $18.37 \pm 2.88$ & n.s. \\
\hline male & & $\mathrm{T}_{3}$ & mo-gran & $39.83 \pm 5.76$ & \\
\hline female & & & & $46.15 \pm 6.93$ & n.s. \\
\hline male & & $\mathrm{T}_{3}$ & mast cell & $37.4 \pm 3.33$ & \\
\hline female & & & & $32.78 \pm 2.98$ & 0.05 \\
\hline male & Thymus & ACTH & lymphocyte & $7.83 \pm 2.38$ & \\
\hline female & & & & $11.67 \pm 1.4$ & 0.02 \\
\hline male & & endorphin & lymphocyte & $7.07 \pm 1.22$ & \\
\hline female & & & & $11.44 \pm 2.2$ & 0.01 \\
\hline male & & $\mathrm{T}_{3}$ & lymphocyte & $21.84 \pm 4.0$ & \\
\hline female & & & & $26.8 \pm 6.9$ & n.s. \\
\hline
\end{tabular}

n.s. $=$ not significant mo-gran = monocyte, macrophage, granulocyte group $;$ perit = peritoneal; Signif $=$ intergender significance.

\section{General effect of one-gene absence}

Histidine decarboxylase enzyme is needed for the synthesis of histamine. If the gene is absent (in mice) there is no histamine production. However, not only histamine but the hormones of the immune cells are touched. In histamine decarboxylase gene knock-out mice serotonin and $\mathrm{T} 3$ contents are elevated and $\mathrm{ACTH}$ as well as endorphin are reduced in the different immune cells [47, 48]. At this time it is not known whether the absence of histamine affects the hormone balance, or the absence of gene acts at gene level.

\section{Hormone transport with local effects}

In the site of inflammation lymphocytes, predominantly memory $\mathrm{T}$ cells appear and secrete endorphin for reducing or killing pain $[17,18,25,26,158]$. In the inflamed dental pulp endorphin containing CD3 cells appear and increase in number [143]. This localized analgesia can be observed also in inflamed paw tissue, where the number of endorphin containing lymphocytes corresponds with the degree of the pain [99]. However, not only the pain caused by inflammation, but visceral pain could be reduced by T cells' endorphin secretion [81, 182].

In the inflamed tissue endorphin is present in macrophages, monocytes, lymphocytes and granulocytes [51, 141, 142], in membrane packed granules, ready for release under the effect of noradrenaline, CRF or cytokines [26]. The cells are in an activated state, naive cells are not present in the inflamed tissue $[26,141,142]$. Although the local effect of endorphin was studied mainly in the central nervous system, it acts locally in other places of the organism. When endorphin was injected into the inflamed paw, this induced analgesia which was inhibited by co-administration of antiserum to endorphin [26]. According to Blalock [18], the local antinociceptive effect of endorphin is very important.

In experimental autoimmune encephalomyelitis (EAE) lymphocytes, mainly $\mathrm{T}$ and natural killer cells 
infiltrate the central nervous system. These cells produce neurotropic factors (e.g. NGF) locally reducing the inflammation and autoimmune processes, protecting myelin $[85,91]$.

Early pregnancy is a typical case of local effects, when lymphocytes interact with the developing embryo. NK cells enriching in the uterus (uNK cells) under the effect of hormones, produced by the trophoblasts secrete angiogenic growth factors. They facilitate implantation, participate in the modification of spiral arteries and help trophoblast differentiation. The secretory function of uNK cells is reprogrammed by the hormonal milieu established by the developing embryo. The cells develop (progesterone) receptors and synthesize mediator substances [79, 101, 119, 179, 180].

\section{CONCLUSIONS}

The data mentioned above unanimously demonstrate that the immune cells produce, contain and secrete "classic" hormones. Only those hormones were not reported in it, which was not sourced. However, it is not clear, whether the presence of these hormones is not more than the capacity of any cell of an organism to produce hormones or it is specific one with an endocrine function. Considering the spreading of the immune cells, the quantitative measurement of the hormones produced seems to be very difficult. However, it can be estimated that the $\mathrm{T} 3$ production of one lymphocyte is tends to zero related to that of the thyroid gland, but considering the huge amount of these cells, their whole hormone synthesis competes with that of the thyroid, or outraces it. It is estimated that about $400-500 \times 10^{9}$ is the number of the lymphocytes in man and only $2.2 \%$ is present in the blood circulation, $41.3 \%$ in the lymph nodes and tonsils, $15.2 \%$ in the spleen, $4.3 \%$ in the gut, $10.9 \%$ in the thymus and $15 \%$ in the bone marrow [180]. Calculating in grams, the mass of lymphocytes is about $1500 \mathrm{~g}$ in man and $1200 \mathrm{~g}$ in women [185], this is equal to that of the brain or the liver. And this is not the whole immune system, the amount of other-also hormone producing -cells were not calculated.

As was seen above, the immune cells unquestionably have also receptors for hormones produced by themselves and for hormones produced by the nervous system, the classic endocrine system or other immune cells. Through these receptors stimulating or inhibiting impulses can arrive which are transmitted inside the cells by transduction pathways.
The basic problem is that the regulation is studied mostly in vitro or ex vivo and in this conditions the results of the regulation can be accepted: for example CRF regulates the ACTH production of lymphocytes. However, if we imagine that in the organism CRF stimulate the ACTH producing machinery in all of the lymphocytes at the same time, the secretion by them could cause massive disturbances. There must be a fine tuning of the mechanism, which is not known presently, acting at gene or receptor level, which determines what cells and in what amount of the hormone should be produced.

An endocrine gland synthesizes and secretes one, specific hormone: Langerhans islets insulin, adrenal medulla epinephrine etc. The cells of the "official" endocrine glands are in general "mono-producers", when the stimulus is coming (from the trop-hormone or the initiating factors, e.g. blood sugar level) they synthesize the hormone. As the above mentioned data showed, the immune cells are "poly-producers", their hormone synthesizing ability is universal, any hormone can be produced by them. This seems to be one of the most important difference between the two systems. The same lymphocyte produces growth hormone, melatonin or ACTH, etc, having genes for the initiation of synthesis and receptors receiving the exogenous (regulatory) impulses.

The other - perhaps the most important - difference between cells of the "official" endocrine glands and hormone-producing immune cells that these latter are mobile. These cells can transport the hormone contained to different parts of the organism and can discharge them arising the target. In addition they are able not only transport the hormones produced by themselves, but can locally produce them. They transport the whole hormone-synthesizing machinery to the place where it can act. The endocrine gland can produce hormones for the blood circulation and from the oceans of signal molecules the receptor bearing cell select the hormone which will act to it. In the case of hormone producing immune cells, the hormone can be produced locally acting only in the site where it is needed. For example, immune cells are accumulating in the site of inflammation producing and discharging endorphin, without narcotizing the organism [127]. This is a cell-targeted paracrine effect, which could be named to cytocrine. However, the hormone synthesizing immune cells can secrete their product also into the blood or lymphatic circulation. The problem is that it was not at all studied the effect of a hormone, produced by an immune cell locally, to the function, which used to be influenced by the hormone produced 
by an endocrine gland. Always the immune function was studied as a target (immunomodulator effect). It is also not known what is the local hormone concentration produced and what concentration would be needed for the effect.

Another important difference between the cells of the "built in" classic and mobile (immune) cells that these latter are not only universal hormone producers, but universal receivers. There are receptors for different hormones in the membrane (and, considering the presence of hormones there, perhaps in the nucleus) of the same cells and the cells can respond to the stimuli. From this aspect the immune cell is a complex individual endocrine unit, a mobile hormone factory having a neuroendocrine regulation. However, as major part of the system is settled in organs (lymph nodes, spleen, bone marrow, gut) the circulating regulators can approach the cells which, after having the stimuli, are able to hormonally influence the cell population around them. This establishes the condition of an intrasystem regulation, a hormonal network inside the immune organ or inside the whole immune system $[62,66,69]$. As it was mentioned, at the bottom of phylogeny, in unicellular animals there are hormones present, functioning as regulators in a mobile cell population organized from individual cells. This function could remain in the higher ranked organisms only in the immune system, as solely this have mobile individual cells (with hormone synthesizing capacity).

Considering the above mentioned facts and suppositions in connection with the immune system, there is a neuro-immune regulation by (endocrine) mediators of the central nervous system, an intra-immune endocrine regulation, a general immune-endocrine regulation (by hormones circulating in the blood with feed-back also to the nervous system) and a mobile, local immunoendocrine regulation, executed by packed transport. This seems to be complicated, however it can better satisfy physiological requirements, than a more simple one.

The cells of the immune system have a highly developed recognition capacity, which helps them during the antibody production and killing of the intruders or the cells, becoming non-self. There are no data whether this or similar recognition capacity would be at the disposal of the endocrine function of these cells, however this is not inconceivable. In this case the mobile immune cells would be targeted (attracted by signal molecules) to a determined cell or group of cells, where their hormone needed (in a packed form) or could fulfil some function. This is well documented already now in the above-mentioned endorphin-inflammation relation as well, as in the case of early pregnancy. when a trophoblast produced hormone (hCG) attracts [167] immune cells $\left(\mathrm{T}_{\text {regs }}\right)$, which have receptors for it, and protect the half-nonself embryo by causing tolerance (although there are no data on the lymphocyte-produced classic hormones by the tolerance-inducing $\mathrm{T}_{\text {regs }}$ ).

For a long time, the immune system was believed for defending the organism from outer invaders (bacteria, etc) up to the realization that its original function was the safeguarding the inner homeostasis, the recognition and elimination of inner non-self features. This broadened our knowledge on the immune system and it was believed, it is a complete one. However, there are not finished or closed knowledge in biology. The immune-endocrine function requires place. At present, hormone synthesis is handled as a side-product of the immune cells, however, it might be equivocal to the other ones. Further investigations are needed in the directions mentioned above to justify the packedtransport hypothesis. As this hypothesis could have also clinical importance, it would be useful to study the endocrine disturbances in case of immune-cell diseases.

\section{REFERENCES}

[1] Alexander H, Zimmermann G, Lehmann M, Pfeiffer R, Schöne E, Leiblein S, Ziegert M. HCG secretion by peripheral mononuclear cells during pregnancy. Domest Anim Endocrinol. 1998; 15: 377-387.

[2] Angele MK, Schwacha MG, Ayala A, Chaudry IH. Effect of gender and sex hormones on immune responses following shock. Shock. 2000; 14: 81-90.

[3] Aoi R, Nakashima I, Kitamura Y, Asai H, Nakano K. Histamine synthesis by mouse T lymphocytes through induced histidine decarboxylase. Immunology. 1989; 66: 219-223.

[4] Arpin C, Pihlgren M, Fraichard A, Aubert D, Samarut J, Chassande O, Marvel J. Effcts of T3R alpha 1 and T3R alpha 2 gene deletion on T and B lymphocyte development. J. Immunol. 2000; 164: 152-160.

[5] Aune TM, Golden HW, McGrath KM. Inhibitors of serotonin synthesis and antagonists of serotonin 1A receptors inhibit T lymphocyte function in vitro and cell-mediated immunity in vivo. J Immunol. 1994; 153: 489-498.

[6] Barkan T, Gurwitz D, Levy G, Weizman A, Rehavi M. Biochemical and pharmacological characterization of the serotonin transporter in human peripheral blood lymphocytes. Eur Neuropsychopharmacol. 2004; 14: 237-243.

[7] Batra A, Okur B, Glauben R, Erban U, Ihbe J, Stroh T, Fedke I, Chang HD, Zeitz M, Siegmund B. Leptin: a critical regulator of CD4 + T-cell polarization in vitro and in vivo. Endocrinology. 2010; 151: 56-62.

[8] Bernard C. Lecons de. physiologie experimentale applliquee a la medicine0. Paris. 1855.

[9] Berczi I. The immune effects of neuropeptides. Baillieres Clin Rheumatol. 1996; 10: 227-257. 
[10] Berczi I. Pituitary hormones and immune function. Acta Pediatr. 1997; 423 (9) Suppl. 70-75.

[11] Berczi I. The stress concept and neuroimmunoregulation in modern biology. Ann N Y Acad Sci. 1998; 30: (3-12).

[12] Berczi I. The role of growth and lactogenic hormone family in immune function. Neuroimmunomodulation. 1994; 1 : 201-216.

[13] Berczi I. Neuroimmune biology- an introduction. In: New Foundation of Biology (eds. I. Berczi and R.M. Gorczynski) Elsevier. 2001.

[14] Berczi I, Baragar FD, Chalmers IM, Keystone EC, Nagy E, Warrington RJ. Hormones in self tolerance and autoimmunity: a role in the pathogenesis in rheumatoid arthritis. Autoimmunity. 1993; 16: 45-56.

[15] Berczi I, Quintanar-Stephano A, Kovács K. The brave new world of neuroimmune biology. In: New insights to neuroimmune biology, Ed. I. Berczi Elsevier. 2010.

[16] Blalock JE. Production of neuroendocrine peptide hormones by the immune system. Prog Allergy. 1988; 43: 1-13.

[17] Blalock JE. Beta-endorphin in immune cells. Immunol Today. 1998; 19: 191-192.

[18] Blalock JE. Proopiomelanocortin and the immune-neuroendocrine connection. Ann N.Y. Acad Sci. 1999; 885: 161172.

[19] Blalock JE, Johnson HM, Smith EM, Torres BA. Enhancement of the in vitro antibody response by thyrotropin. Biochem Biophys Res Commun. 1984; 125: 30-34.

[20] Blalock JE, Smith EM. A complete regulatory loop between the immune and neuroendocrine systems. Fed Proc. 1985; 44: 108-111.

[21] Bost KL, Smith EM, Wear LB, Blalock JE. Presence of $\mathrm{ACTH}$ and its receptor on a B lymphocytic cell line: a possible autocrine function for a neuroendocrine hormone. J Biol Regul Homeost Agents. 1987; 1: 23-27.

[22] Brennan CP, Hendricks GL, El-Sheikh TM, Mashaly MM Melatonin and the enhancement of immune responses in immature male chickens. Poultry Sci. 2002; 81: 371-375.

[23] Brooks KH. Adrenocorticotropin (ACTH) functions as a late-acting B cell growth factor and synergizes with interleukin5. J Mol Cell Immunol. 1990; 4: 327-335.

[24] Buckley AR. Prolactin. a lymphocyte growth and survival factor. Lupus. 2001; 10: 684-690.

[25] Cabot PJ. Immune-derived opioids and peripheral antinociception. Clin Exp Pharmacol Physiol. 2001; 28: 230-232.

[26] Cabot PJ, Carter L, Gaiddon C, Zhang Q, Schafer M, Loeffler JP, Stein C. Immune cell-derived beta-endorphin. Production release, and control of iflammatory pain in rats. J Clin Invest. 1997; 100: 142-148.

[27] Cannon JG, Pierre BA. Gender differences in host defense mechanism. J Psychiatr Res. 1997; 31: 99-113.

[28] Cardinali DP, Esquifino AJ, Srinivasan V, Pandi-Perumal SR. Melatonin and the immune system in aging. Neuroimmunomodulation. 2008; 15: 272-278.

[29] Cao J, Papadopulou N, Kempuraj D, Boucher WS, Sugimoto K, Petrulo CL, Theoharides TC. Human mast cells express corticotropin-releasing hormone ( $\mathrm{CRH})$ receptors and $\mathrm{CRH}$ leads to selective secretion of vascular endothelial growth factor. J Immunol. 2005; 174: 7665-7675.

[30] Carillo-Vico A, Calvo JR, Abreu P, Lardone PJ, GarciaMaurino S, Reiter RJ, Guerrero JM. Evidence of melatonin synthesis by human lymphocytes and its physiological significance: possible role as intracrine, autocrine, and/or paracrine substance. FASEB J. 2004; 18: 537-539.

[31] Carillo-Vico A, Lardone PJ, Fernadez-Santos JM, MartinLacave I, Calvo JR, Karasek M, Guerrero JM. Human lymphocyte-synthesized melatonin is involved in the regulation of the interleukin-2/interleukin-2 receptor system. J Clin Endocrinol Metab. 2005; 90: 992-1000.

[32] Caroleo MC, Dona G, Nistcó G. Melatonin restores immunodepression in aged and cyclophosphamide-treated mice. Ann NY Acad Sci. 1994; 719: 343-352.

[33] Carr DJ, Blalock JE. "Classical" neuroendocrine peptide hormones produced by cells of the immune system. Brain Behav Immun. 1988; 2: 328-334.

[34] Carr DJ, Blalock JE. From the neuroendocrinology of lymphocytes toward a molecular basis of the network theory. Horm Res. 1989; 31: 76-80.

[35] Carr DJ, DeCosta BR, Jacobson AE, Rice KC, Blalock JE. Corticotropin-releasing hormone augments natural killer cell activity through a naloxone-sensitive pathway. J Neuroimmunol. 1990; 28: 53-61.

[36] Caspar-Bauguil S, Cousin B, Bour S, Castiella L, Penicaud L, Carpéné C. Adipose tissue lymphocytes: types and roles. J Physiol Biochem. 2009; 65: 423-436.

[37] Chao TC. Female sex hormones and the immune systems. Changgeng Yi Xue Za Zhi. 1996; 19: 96-106.

[38] Christensen ST, Guerra CF, Awan A, Wheatley DN, Satir P. Insulin receptor-like proteins in Tetrahymena thermophila ciliary membranes. Curr Biol. 2003; 13: R50-R52.

[39] Clarke BL, Gebhardt BM, Blalock JE. Mitogen-stimulated lymphocytes release biologically active corticotropin. Endocrinology. 1993; 132: 983-988.

[40] Clarke BL, Moore DR, Blalock JE. Adrenocorticoptropic hormone stimulates a transient calcium uptake in rat lymphocytes. Endocrinology. 1994; 135: 1780-1786.

[41] Csaba G. Mechanism of the formation of mast cell granules. VII. Participation of amines and basic proteins in the formation of the mast cell granule. Analysis of the heterogeneity of mast cells. Acta Biol Hung. 1971; 22: 155168.

[42] Csaba G. Phylogeny and ontogeny of hormone receptors: the selection theory of receptor formation and hormonal imprinting. Biol Rev Camb Phylos Soc. 1980; 55: 47-63.

[43] Csaba G. The present state in the phylogeny and ontogeny of hormone receptors. Horm Metab Res. 1984; 16: 329335.

[44] Csaba G. Hormonal imprinting: phylogeny. ontogeny, diseases and possible role in present-day human evolution. Cell Biochem Funct. 2008; 26: 1-10.

[45] Csaba G, Kovács P. Perinuclear localization of biogenic amines (serotonin and histamine) in rat immune cells. Cell Biol Int. 2006; 30: 861-865.

[46] Csaba G, Kovács P. Hormones in the nucleus of mast cells: confocal microscopic immunocytochemical observations. Horm Metab Res. 2009; 41: 621-625.

[47] Csaba G, Kovács P, Buzás E, Mazán M, Pállinger É. Serotonin content is elevated in the immune cells of histidine decarboxylase knock-out (HDCKO) mice. Focus on mast cells. Inflamm Res. 2007; 56: 89-92.

[48] Csaba G, Kovács P, Buzás E, Mazán M, Pállinger Eacute. Histidine decarboxylase (HDC) knock out mouse immune cells have altered expression of ACTH triiodothyronine and endorphin. Inflamm Res. 2007; 56: 428-431.

[49] Csaba G, Gaál A, Kovács P. Simon G and Kôhidai L. Prolonged elevation of insulin content in the unicellular Tetrahymena after insulin treatment: induction of insulin production or storage? Cell Biochem Funct. 1999; 17: 165173.

[50] Csaba G, Karabélyos C, Inczefi-Gonda Á, Pállinger É. Three-generation investigation on serotonin content in rat 
immune cells long after beta-endorphin exposure in late pregnancy. Horm Metab Res. 2005; 37: 172-177.

[51] Csaba G, Kovács P, Pállinger É. Beta-endorphin in granulocytes. Cell Biol Int. 2002; 28: 741-743.

[52] Csaba G, Kovács P, Pállinger É. Prolonged effect ot a single serotonin treatment in adult age on the serotonin and histamine content of white blood cells and mast cells of rat. Cell Biochem Funct. 2003; 21: 191-194.

[53] Csaba G, Kovács P, Pállinger É. Effect of endorphin exposure at weaning on the endorphin and serotonin content of white blood cells and mast cells in adult rat. Cell Biochem Funct. 2004; 22: 197-200.

[54] Csaba G, Kovács P, Pállinger É. Prolonged impact of five imprinters on the serotonin content of white blood cells and mast cells of weanling rats: outstanding effect of benzpyrene and chlorpheniramine. Cell Biol Int. 2004; 28: 217-222.

[55] Csaba G, Kovács P, Pállinger É. Immunologically demonstrable hormones and hormone-like molecules in rat white blood cells and mast cells. Cell Biol Int. 2004; 28: 487-490.

[56] Csaba G, Kovács P, Pállinger É. Effect of inhibition of triiodothyronine (T3) production by thiamazole on the T3 and serotonin content of immune cells. Life Sci. 2005; 20432052.

[57] Csaba G, Kovács P, Pállinger É. Influence of in vitro and in vivo insulin treatment on the hormone (hustamine, serotonin, endorphin and triiodothyronine) content of thymus and spleen cells. Life Sci. 2006; 78: 1034-1037.

[58] Csaba G, Kovács P, Pállinger É. Changes in the endorphin and serotonin content of rat immune cells during adulthood following maternal exposure to ethanol during pregnancy and lactation. Alcohol. 2006; 38: 111-116.

[59] Csaba G, Kovács P, Pállinger É. Hormones in the nucleus. Immunologically demonstrable biogenic amines (serotonin. histamine) in the nucleus of rat peritoneal mast cells. Life Sci. 2006; 78: 1871-1877.

[60] Csaba G, Kovács P, Pállinger É. Transgenerational effect of neonatal vitamin $\mathrm{A}$ or $\mathrm{D}$ treatment (hormonal imprinting) on the hormone content of rat immune cells. Horm Metab Res. 2007; 39: 197-201.

[61] Csaba G, Kovács P, Pállinger É. Impact of neonatal imprinting with vitamin $\mathrm{A}$ or $\mathrm{D}$ on the hormone content of rat immune cells. Cell Biochem Funct. 2007; 25: 717-721.

[62] Csaba G, Kovács P. Pállinger É. In vitro effect of biogenic amines on the hormone content of immune cells of peritoneal fluid and thymus. Is there a hormonal network inside the immune system? Cell Biol Int. 2007; 31: 224-228.

[63] Csaba G, Kovács P, Tóthfalusi L, Pállinger É. Prolonged effect of stress (water and food deprivation) at weaning or in adult age on the triiodothyronine and histamine content of immune cells. Horm Metab Res. 2005; 37: 711-715.

[64] Csaba G, Oláh I. Mechanism of the formation of mast cell granules. I. Ultrastructural and histochemical study in a model consisting of living cells. Acta Biol Hung. 1968; 19: 347-362.

[65] Csaba G, Pállinger É. Effect of single neonatal or repeated benzpyrene exposure on the serotonin content of immune cells in young male rats. Acta Physiol Hung. 2004; 91: 205210.

[66] Csaba G, Pállinger É. In vitro effect of hormones on the hormone content of rat peritoneal and thymic cells. Is there an endocrine network inside the immune system?. Inflamm Res. 2007; 56: 447-451.

[67] Csaba G, Pállinger É. Gender dependence in the hormone content of the immune cells. Acta Physiol Hung. 2009; 96: 45-50.
[68] Csaba G, Pállinger É. Thyrotropic hormone (TSH) regulation of triiodothyronine (T3) concentration in immune cells. Inflamm Res. 2009; 58: 151-154.

[69] Csaba G, Pállinger É. Is there a possibility of intrasystem regulation by hormones produced by the immune cells? Experiments with extremely low concentrations of hormones. Acta Physiol Hung. 2009; 96: 369-374.

[70] Csaba G, Sudár F, Ubornyák L. Comparative study of the internalization and nuclear localization of amino acid type hormones in Tetrahymena and rat lymphocytes. Exp Clin Endocrinol. 1983; 82: 61-67.

[71] Csaba G, Tekes K, Pállinger É. Influence of perinatal stress on the hormone content in immune cells of adult rats: dominance of ACTH. Horm Metab Res. 2009; 41: 617-620.

[72] Daniluk J, Kandefer-Szerszen M. The effect of alcohol on the immune system and cytokines. Postepy Hig Med Dosw. 1998; 52: 49-65.

[73] De Bellis A, Bizzarro A, Pivonello R, Lombardi G, Bellastella A. Prolactin and autoimmunity. Pituitary. 2005; 8: 25-30.

[74] DeKeyser FG, Winchurch RA, Munster A. Interactions of ACTH and TGF beta on monocyte proliferation: implications for trauma and burn patients. Res Nurs Health. 1996; 19: 511-516.

[75] Dérfalvi B, Sallai P, Német K, Szalai C, Kenesei E, Tulassay T, Falus A. The in vitro effect of recombinant human growth hormone on lymphocyte and granulocyte function in healthy and uremic children. Orv Hetil. 1998; 139: 18471850.

[76] Dixit VD, Marahrens M, Parvizi N. Transport stress modulates adrenocorticotropin secretion from peripheral bovine lymphocytes. J Anim Sci. 2001; 79: 729-734.

[77] Dixit WD, Mielenz M, Taub DD, Parvizi N. Leptin induces growth hormone secretion from peripheral blood mononuclear cells via a protein kinase $\mathrm{C}$ and nitric oxide-dependent mechanism. Endocrinology. 2003; 144: 5595-5603.

[78] Dixit VD, Parvizi N. Pregnancy stimulates secretion of adrenocorticotropin and nitric oxide from pepripheral bovine lymphocytes. Biol Reprod. 2001; 64: 242-248.

[79] Dosiou C, Giudice LC. Natural killer cells in pregnancy and recurrent pregnancy loss: endocrine and immunologic perspective. Endocr Rev. 2005; 26: 44-62.

[80] Dvorak AM. New aspects of mast cell biology. In Arch Allergy Immunol. 1997; 114: 1-9.

[81] Falus A. Histamine: biology and medical aspects. Karger, Basel-Budapest 2004.

[82] Ferreira AC, de Carvalho Cardoso L, Rosenthal D, de Carvalho DP. TCa2+/NADPH-dependent $\mathrm{H} 2 \mathrm{O} 2$ generation is partially inhibited by propylthiouracil and methimazole. Eur J Biochem. 2003; 270: 2363-2368.

[83] P. Fernandez-Riejos, S. Najib, Santos-Alvarez J, MartinRomero C, Pérez-Pérez A, González-Yanes C, SanchezMargalet V. Role of leptin in the activation of immune cells. Med Inflamm. 2010. Epub.

[84] Finocchiaro LM, Arzt ES, Fernandez-Castelo S, Criscuolo M, Finkielman S, Nachmod VE. Serotonin and melatonin synthesis in peripheral blood mononuclear cells. stimulation by interferon-gamma as part of an immunomodulatory pathway. J Interferon Res. 1988; 8: 705-716.

[85] Flügel A, Matsumoro $\mathrm{K}$, Neumann $\mathrm{H}$, Klinkert WE, Birnbacher R, Lassmann H, Otten U, Wekerle H. Antiinflammatory activity of nerve growth factor in experimental autoimmune encephalomyelitis: inhibition of monocyte transendothelial migration. Eur J Immunol. 2001; 31: 11-22. 
[86] Gala RR. Prolactin and growth hormone in the regulation of the immune system. Proc Soc Exp Biol Med. 1991; 198: 513-527.

[87] Garcia-Perganeda A, Pozo D, Guerrero JM, Calvo JR. Signal transduction for melatonin in human lymphocytes: involvement of a pertussis toxin-sensitive $G$ protein. J Immunol. 1997; 159: 3774-3781.

[88] Goodman DW, Isakson PC. Mitogen activation of resting lymphocytes exposes cryptic insulin receptors. J Biol Chem. 1993; 268: 4207-4215.

[89] Guarcello V, Weigent DA, Blalock JE. Growth hormone releasing hormone receptors on thymocytes and from rats. Cell Immunol. 1991; 136: 291-302.

[90] Haddad EE, Mashaly MM. Effect of thyrotropin-releasing hormone, triiodothyronine and chicken growth hormone on plasma concentrations of thyroxine, triiodothyronine, growth hormone, and growth of lymphoid organs and leukocyte populations in immature male chickens. Poultry Sci. 1990; 69: 1094-1102.

[91] Hammarberg H, Lidman O, Lundberg C, Eltayeb SY, Gielen AW, Muhallab S, Svenningsson A, Lindá $H$, van der Meide PH, Cullheim S, Olsson T, Piehl F. Neuroprotection by encephalomyelitis: rescue of mechanically injured neurons and neurotrophin production by CNS-infiltrating T and natural killer cells. J Neurosci. 2000; 20: 5283-5281.

[92] Harbour DV, Smith EM, Blalock JE. Splenic lymphocyte production of an endorphin during endotoxic shock. Brain Behav Immun. 1987; 1: 123-133.

[93] Harbour DV, Galin FS, Hughes TK, Smith EM, Blalock JE. Role of leukocyte-derived pro-opiomelanocortin peptides in endotoxic shock. Circ Shock. 1991; 35: 181-191.

[94] Harbour DV, Kruger TE, Coppenhaver D, Smith EM, Meyer WJ. Differential expression and regulation of thyrotropin (TSH) in T cell lines. Mol Cell Endocrinol. 1989; 64: 229-241.

[95] Harbour McMenamin D, Smith EM, Blalock JE. Production of immunoreactive chorionic goadotropin during mixed lymphocyte reactions: a possible selective mechanism for genetic diversity. Proc Natl Acad Sci. 1986; 83: 68346838.

[96] Hashemi FB, Hughes TK, Smith EM. Human immunodeficiency virus induction of corticotropin in lymphoid cells. J Clin Endocrinol Metab. 1998; 83: 4373-4381.

[97] Hellstrand K, Czerkinsky C, Ricksten A, Jansson B, Asea A, Kylefjord H, Hermondsson S. Role of serotonin of interferon-gamma production by human natural killer cells. J Interferon Res. 1993; 13: 33-38.

[98] Hendricks GL, Mashaly MM. Effects of corticotrpin releasing factor on the production of adrenocorticotropic hormone by leukocyte populations. Br Poultry Sci. 1998; 39: 123127.

[99] Hermanussen S, Do M, Cabot PJ. Reduction of betaendorphin-containing immune cells in inflamed paw tissue corresponds with a reduction in immune-derived antinociception: reversible by donor activated lymphocytes. Anesth Analg. 2004; 98: 723-729.

[100] Huang L, Li ZY, Xu SY, Chen MZ. Effects of thyroxine on IgM production and beta-adrenergic receptor on lymphocyte in mice. Sheng Li Xue Bao. 1990; 42: 469-475.

[101] Hunt JS, Petroff MG, Burnett TG. Uterine leukocytes: key players in pregnacy. Semin Cell Dev Biol. 2000; 11: 127137.

[102] Igaz P, Novák I, Lázaár E, Horváth B, Héninger E, Falus A. Bidirectional communication between histamine and cytokines. Inflamm Res. 2001; 50: 123-128.
[103] Jara LJ, Benitez G, Medina G. Prolactin, dendritic cells, and systemic lupus erythematosis. Autoimmun Rev. 2008; 7: 251-255.

[104] Johnson EW, Blalock JE, Smith EM. ACTH receptor mediated induction of leukocyte cyclic AMP. Biochem Biophys Res Commun. 1988; 157: 1205-1211.

[105] Johnson HM, Smith EM, Torres BA, Blalock JE. Regulation of the in vitro antibody response by neuroendocrine hormones. Proc Natl Acad Sci. 1982; 79: 4171-4174.

[106] Kao TL, Meyer WJ. Stimularory effects of immunoreactive growth hormone on proliferation of a human lymphocyte cell line. Cancer Lett. 1994; 81: 13-18.

[107] Kavelaars A, Ballieux RE, Heijnen CJ. The role of IL-1 in the corticotropin-releasing factor and arginine-vasopressininduced secretion of immunoreactive beta-endorphin by human peripheral blood mononuclear cells. J Immunol. 1989; 142: 2338-2342.

[108] Kelley KW, Weigent DA, Kooijman R. Protein hormones and immunity. Brain Behav Immun. 2007; 2: 384392.

[109] Kim SY, Lim JH, Choi SW, Kim MST, Kim MS, Cho YS, Chun E, Lee KY. Preferential effects of leptin on CD4 T cells in central and peripheral immune system are critically linked to the expression of leptin receptor. Biochem Biophys Res Commun. 2010; 384: 562-568.

[110] Kliger CA, Gehad AE, Hulet RM, Roush WB, Lillehoj HS, Mashaly MM. Effects of photoperiod and melatonin on lymphocyte activities in male broiler chickens. Poult Sci. 79(200): 18-25.

[111] Kibo Y, Nakano K. Regulation of histamine synthesis in mouse CD4+ and CD8+ T lymphocytes. Inflamm Res. 1999; 48: 149-153.

[112] Kiess W, Holtmann H, Bitenandt O, Eife R. Modulation of lymphoproliferation by human growth hormone. Eur J Pediatr. 1983; 140: 47-50.

[113] Kruger TE, Blalock JE. Cellular requirements for thyrotropin enhancement of in vitro antibody production. $\mathrm{J}$ Immunol. 1986; 137: 197-200.

[114] Kruger TE, Smith LR, Harbour DV, Blalock JE. Thyrotropin: an endogenous regulator of the in vitro immune response. J Immunol. 1989; 142: 744-747.

[115] Kvetnoi IM, Ingel E. Hormonal function of neuroendocrine cells, role of new biological phanomenon in the regulation of homeostasis. Bull Exp Biol Med. 2000; 130: 10271030 .

[116] Kvetny J. The effect of lithium on the peripheral turnover of thyroxine and triiodothyronine. Acta Endocrinol. 1978; 89: 687-692.

[117] Lemarchand-Béraud T, Holm A-C, Scazziga BR. Triiodothyronine and thyroxine nuclear receptors in lymphocytes from normal. hyper- and hypothyroid subjects. Acta Endocrinol. 1977; 85: 44-54.

[118] Lemke $\mathrm{H}$, Lange $\mathrm{H}$. Is there a maternally induced immunological imprinting phase a la Konrad Lorenz? Scand J Immunol. 1999; 50: 348-354.

[119] Leonard S, Murrant C, Tayade C, van den Heuvel M, Watering R, Croy BA. Mechanisms regulating immune cell contributions to spiral artery modification -facts and hypotheses - a review. Placenta. 2006; 27: Suppl A S40-S46.

[120] Lenard J. Mammalian hormones in microbial cells. Trends Biochem Sci. 1992; 17: 147-150.

[121] LeRoith D, Shiloach J, Roth J, Lesniak MA. Evolutionary origins of veretebrate hormones: substances similar to mammalian insulins are native to unicellular eukaryotes. Proc Natl Acad Sci USA. 1980; 77: 6184-6188. 
[122] LeRoith D, Shiloach J, Roth J, Lesniak MA. Insulin or a closely related molecule is native to Escherichia coli. J Biol Chem. 1981; 256: 6533-6536.

[123] LeRoith D, Liotta AS, Roth J, Shiloach J, Lewis ME, Perth CB, Krieger DT. Corticotropin and beta-endorphinlike materials are native to unicellular organisms. Proc Natl Acad Sci USA. 1982; 79: 2086-2090.

[124] Lissoni P. The pineal gland as a central regulator of cytokine network. Neuro Endocrinol Lett. 1999; 20: 343-349.

[125] Lyons PD, Blalock JE. The kinetics of ACTH expression in rat leukocyte. J Neuroimmunol. 1995; 31: 103-112.

[126] Lyons PD, Blalock JE. Pro-opiomelanocortin gene expression and protein processing in rat mononuclear cells. $\mathrm{J}$ Neuroimmunol. 1997; 78: 47-56.

[127] Machelska H. Targeting of opioid producing leukocytes for pain control. Neuropeptides. 2007; 41: 355-363.

[128] Maier CC, Marchetti B, LeBoeuf RD, Blalock JE. Thymocytes express a mRNA that is identical to hypothalamic luteinizing hormone mRNA. Cell Mol Neurobiol. 1992; 12: 447-454

[129] Marcola KE, Cline MJ, Golde DW. Growth hormone stimulation of normal and leukemic human T-lymphocyte proliferation in vitro. Blood. 1981; 58: 337-340.

[130] Markus RP, Ferreira ZS, Fernandes PA, Cecon E. The immune-pineal axis: a shuttle between endocrine and paracrine melatonin sourxes. Neuroimmunomodulation. 2007; 14: 126-133.

[131] Martins E, Ferreira ACF Jr, Skorupa AL, Afeche SC, Cipolla-Neto J, Costa Rosa LFBP. Tryptophan consumption and indoleamines production by peritoneal cavity macrophages. J Leukocyte Biol. 2004; 75: 1116-1121.

[132] Maruna P, Gürlich R, Frasko R, Leptin - Jr. a new acute phase reactant. Vnitr Lek. 2001; 47: 478-483.

[133] Mascanfroni I, Montesinos Mdel M, Sisperreguy S, Cervi L, Ilarreguy JM, Ramseyer VD, Masini-Repiso AM, Targovnik HM, Rabinovich GA, Pellizas CG. Control of dendritic cell maturation and function by triiodothyronine. FASEB J. 2008; 22: 1032-1042.

[134] Mascanfroni ID, Montesinos Mdel M, Alamino VA, Susperreguy S, Nicola JP, Ilarreguy JM, Masini-Repiso AM, Rabinovich GA, Pellizas CG. Nuclear factor (NF)-kappaBdependent thyroid hormone receptor beta 1 expression controls dendritic cell function via AKT signaling. J Biol Chem. 2010; 285: 9569-9582.

[135] Mashaly MM, Trout JM, Hendricks GL. The endocrine function of the immune cells in the initiation of humoral immunity. Poult Sci. 1993; 72: 1289-1293.

[136] Mashaly MM, Trout JM, Hendricks G, al-Dokhi LM, Gehad A. The role of neuroendocrine immune interactions in the initiation of humoral immunity in chickens. Domest Anim Endocrinol. 1998; 15: 409-422.

[137] Meazza C, Pagani S, Travaglino P, Bozzola M. Effect of growth hormone $(\mathrm{GH})$ on the immune system. Pediatr Endocrinol Rev Suppl. 2004; 3: 490-495.

[138] Mendez I, Carino C, Diaz L. Prolactin in the immunological system: synthesis and biological effects. Rev Invest Clin. 2005; 57: 447-456

[139] Merlot E, Couret D, Otten W. Prenatal stress: fetal imprinting and immunity. Brain Behav Immun. 2008; 22: 42-51.

[140] Montgomery DW. Prolactin production by immune cells. Lupus. 2001; 10: 665-675.

[141] Mousa SA, Zhang Q, Sitte N, Stein C. beta-endorphincontaining memory cells and mu-opioid receptors undergo transport to peripheral inflamed tissue. J Neuroimmunol. 2001; 115: 71-78.
[142] Mousa SA, Shakibaei M, Sitte N, Schafer M, Stein C. Subcellular pathways of beta-endorphin synthesis. processing and release from immunocytes in inflammatory pain. Endocrinology. 2004; 145: 1331-1341.

[143] Mudie AS, Holland GR. Local opioids in the inflamed dental pulp. J Endod. 2006; 32: 319-323.

[144] Müller T, Dürk T, Blumenthal B, Grimm M, Cicko S, Panther E, Sorichter S, Herouy Y, Di Virgilio F, Ferrari D, Norgauer J, Idtko M. Stimulation of splenic T-lymphocyte function by endogenous serotonin and by low-dose exogenous serotonin. PLoS One. 2009; 4: e6453.

[145] Nagy E, Berczi I. Hypophysectomized rats depend on residual prolactin for survival. Endocrinology. 1991; 128: 2776-2784.

[146] Nakanishi K, Taniguchi Y, Onji M. Triiodothyronine enhances expression of the interleukin-2 receptor alpha chain. Endocr J. 1999; 46: 437-442.

[147] Oh C, Suzuki S, Nakashima I, Yamashita K, Nakano K. Histamine synthesis by non-mast cells through mitogen-dependent induction of histidine decarboxylase. Immunology. 1988; 65: 143-148.

[148] Ohta K, Shichiri M, Kameya T, Matsubara O, Imai T, Marumo F, Hirata Y. Thymic hyperplasia as a source of ectopic ACTH production. Endocr J. 2000; 47: 487-492.

[149] Packard KA, Khan MM. Effects of histamine on Th1/Th2 cytokine balance. Int Immunopharmacol. 2003; 3: 909920.

[150] Padgett DA, Glaser R. How stress influences the immune response. Trends Immunol. 2003; 24: 444-448.

[151] Paegelow I, Werner H, Hagen M, Wartner U, Lange P. Influence of serotonin on lymphokine secretion in vitro. Int $\mathrm{J}$ Immunopharmacol. 1985; 7: 889-896.

[152] Pállinger É, Kovács P, Csaba G. Presence of hormones (triiodothyronine, serotonin and histamine) in the immune cells of newborn rat. Cell Biol Int. 2005; 29: 826-830.

[153] Pállinger É, Csaba G. Effect of single early gestational alcohol consumption on the insulin binding by immune cells of adult rats. Inflamm Res. 2005; 54: 483-484.

[154] Pállinger É, Csaba G. Influence of acute stress on the triiodothyronine (T3) and serotonin content of rat's immune cells. Acta Physiol Hung. 2005; 92: 47-52.

[155] Pállinger É, Csaba G. Presence and distribution of biogenic amines (histamine. serotonin and epinephrine) in immunophenotyped human immune cells. Inflamm Res. 2008; 57: 530-534.

[156] Pállinger É, Csaba G. A hormone map of human immune cells showing the presence of adrenocorticotropic hormone. triiodothyronine and endorphin in immunophenotyped white blood cells. Immunology. 2008; 123: 584-589.

[157] Pállinger É, Tóthfalusi L, Csaba G. Prolonged effect of endorphin treatment during pregnancy in the rat on the histamine content of immune cells of F1 and F2 offspring generations. Cell Biochem Funct. 2006; 24: 287-290.

[158] Panerai AE, Sacerdote P. Beta-endorphin in the immune system: a role at last? Immunol Today. 1997; 18: 317-319.

[159] Peeva E, Venkatesh J, Michael D, Diamond B. Prolactin as a modulator of B cell function: implications for SLE. Biomed Pharmacother. 2004; 58: 310-319.

[160] Petrovsky N. Towards a unified model of neuroendocrineimmune interaction. Immunol Cell Biol. 2001; 79: 350-357.

[161] Pietschmann P, Gollob E, Brosch S, Hahn P, Kudlacek S, Wilheim M, Woloszczuk W, Peterlik M, Tragl KH. The effect of age and gender on cytokine production by peripheral blood mononuclear cells and markers of bone metabolism. Exp Gerontol. 2003; 38: 1119-1127. 
[162] Piolo C, Caroleo MC, Natico G, Dona G. Melatonin increases antigen presentation and amplifies specific and non specific signals for T-cell proliferation. Int J Immunopharmacol. 1993; 15: 463-468.

[163] Radogna F, Diederich M, Ghibelli L. Melatonin. A pleiotropic molecule regulating inflammation. Biochem Pharmacol. 2010; 80: 1844-1852.

[164] Romeo J, Warnberg J, Nova E, Diaz LE, Gómez Martinez S, Marcos A. Moderate alcohol consumption and the immune system: a review. Br J Nutr. 2007; Suppl 1: S111-S115.

[165] Rosenberger $P$, Mühlbauer E, Weissmüller T, Rommelspacher H, Sinha P, Wernecke KD, Finchk U, Rettig J, Kox WJ, Spies CD. Decreased proopiomelanocortin mRNA in lymphocytes of chronic alcoholics after intravenous human corticotropin releasing factor injection. Alcohol Clin Exp Res. 2003; 27: 1693-1700.

[166] Schimpf RM, Repellin AM. In vitro effect of human growth hormone on lymphocyte transformation and lymphocyte growth factors secretion. Acta Endocrinol. 1989; 120: 745752 .

[167] Schumacher A, Brachwitz N, Sohr S, Engeland K Lamgwisch S, Dolapchieva M, Alexander T, Taran A, Malfertheiner SF, Costa SD, Zimmermann G, Nitschke C, Volk HD, Alexander H, Gunzer M, Zenclussen AC. Human chorionic gonadotropin attracts regulatory $\mathrm{T}$ cells into the fetal-maternal inteface during early human pregnancy. J Immunol. 2009; 182: 5488-5497.

[168] Selye H. The mast cells, Butterworths, Washington, 1965.

[169] Siebler T, Robson H, Bromley M, Stevens DA, Shalet SM, Williams GR. Thyroid status affects number and localization of thyroid hormone receptor expressing mast cells in bone marrow. Bone. 2002; 30: 259-266.

[170] Slebodzinski AB, Brzezinska-Slebodzinska E. Local generation of triiodothyronine by the mammary gland as a source of measurable quantities of the hormone in milk. Endocr Regul. 1991; 25: 83-89.

[171] Smekers L, Golstein J, Vanhaelst L. Measurement of thyroxine conversion to triiodothyronine using human lymphocytes. A useful laboratory technique. J Endocrinol Invest. 1983; 6: 113-117.

[172] Smith EM, Blalock JE. Human lymphocyte production of corticotropin and endorphin-like-substances: asociation with leukocyte interferon. Proc Natl Acad Sci USA. 1981; 78: 7530-7534.

[173] Smith EM, Blalock JE. A molecular basis for interactions between the immune and neuroendocrine systems. Int J Neurosci. 1988; 38: 455-464.

[174] Smith EM, Phan M, Kruger TE, Coppenhaver DH, Blalock J.E. Human lymphocyte production of immunoreactive thyrotropin. Proc Natl Acad Sci. 1983; 80: 6010-6013.

[175] Smith EM, Harbour-McMenamin D, Blalock JE. Lymphocyte production of endorphins and endorphin-mediated immunoregulatory activity. J Immunol. 1985; 135: 779s$782 \mathrm{~s}$

[176] Srinivasan V, Maestroni GJ, Cardinali DP, Esquifino AI, Perumal SR, Miller SC. Melatonin, immune function and aging. Immun Ageing. 2005; 29: 17.

[177] Szabo G. Consequences of alcohol consumption on host defence. Alcohol Alcohol. 1999; 34: 830-841.

[178] Szabo G, Mandrekar P. A recent perspective on alcohol, immunity, and host defense. Alcohol Clin Exp Res. 2009; 33: 220-232.

[179] Szekeres-Bartho J. Immunological relationship between the mother and the fetus. Int Rev Immunol. 2002; 21: 471495.
[180] Trepel F. Number and distribution of lymphocytes in man. A critical analysis. J Mol Med. 1974; 52: 511-515.

[181] Verma-Gandhu M, Bercik P, Motomura Y, Verdu EF, Khan WI, Blennerhassett PA, Wang L, El-Sharkawy RT. Collins SM. CD4 + T-cell modulation of visceral nociceptin in mice. Gastroenterology. 2006; 130: 1721-1728.

[182] Verma-Gandhu M, Verdu EF, Cohen-Lyons D, Collins SM. Lymphocyte-madiated regulation of beta-endorphin int he myenteric plexus. Am J Physiol Gastrointest Liver Physiol. 2007; 292: G344-G348.

[183] Wall JR, Twohig P, Chartier B. Effects of experimental hyper- and hypothyroidism on numbers of blood mononuclear cells and immune function in rats and guinea pigs. $\mathbf{J}$ Endocrinol. 1981; 91: 61-67.

[184] Tsampalas M, Gridelet V, Berndt S, Foidart J-M, Geenen V, Perrier d'Hauterive S. Human chorionic gonadotropin. A hormone with immunological and angiogenic properties. J Repr Immunol. 2010; 85: 93-98.

[185] Ulijaszek SJ, Johnston FE, Preece MA. The Cambridge encyclopedia of human growth and development. Cambridge University Press. 1998; :.

[186] Verthelyi D. Sex hormones as immunomodulators in health and disease. Int Immunopharmacol. 2001; 1: 983-993.

[187] Weigent DA, Baxter JB, Wear WE, Smith LR, Bost KL, Blalock JE. Production of immunoreactive growth hormone by mononuclear leukocytes. FASEB J. 1988; 2: 2812-2818.

[188] Weigent DA, Blalock JE. Immunoreactive growth hormonereleasing hormone in rat leukocytes. J Neuroimmunol. 1990; 29: 1-13.

[189] Weigent DA, Blalock JE. The production of growth hormone by subpopulations of rat mononuclear leukocytes. Cell Immunol. 1991; 135: 55-65.

[190] Weigent DA, Blalock JE. Effect of the administration of growth-hormone-producing lymphocytes on weight gain and immune function in dwarf mice. Neuroimmunomodulation. 1994; 1: 50-58

[191] Weigent DA, Blalock JE. Associations between the neuroendocrine and immune systems. J Leukoc Biol. 1995; 58 : 137-150.

[192] Wermerskirchen AS, LaTocha DH, Clarke BL. Adrenocorticotropic hormone controls Concanavalin A activation of rat lymphocytes by modulating IL-2 production. Life Sci. 2000; 67: 2177-2187.

[193] Winkler A, Schmidt LG, Rommelspacher H, Melzig MF. Quantification of proopiomelanocortin mRNA in peripheral lymphocytes of alcoholics. Alcohol. 1998; 15: 43-50.

[194] Winoto A. and Littman D.R.. Nuclear hormone receptors in T lymphocytes. Cell 109 (2002) Suppl: S57-S66.

[195] van Woudenberg AD, Metzelaar MJ, van der Kleij AA, de Wied D, Burbach JP, Wiegant VM. Analysis of proopiomelanocortin (POMC) messenger ribonucleic acid and POMC-derived peptides in human peripheral blood mononuclear cells: no evidence for lymphocyte-derived POMC system. Endocrinology. 1993; 133: 1922-1933.

[196] Yao C, Zhang J, Wang L, Guo Y, Tian T. Inhibitory effects of thyroxine on cytokine production by $\mathrm{T}$ cells in mice. Int Immunopharmacol. 2007; 15: 1747-1754.

[197] Yoshida A, Ishioka C, Kimata H, Mikawa H. Recombinant human growth hormone stimulate B cell immunoglobulin synthesis and proliferation in serum-free medium. Acta Endocrinol. 1992; 126: 524-529.

[198] Young MR, Kut JL, Coogan MP, Wright MA, Young ME, Matthews J. Stimulation of splenic T-lymphocyte function by endogenous serotonin and by low-dose exogenous serotonin. Immunology. 1993; 80: 395-400. 